\title{
Preeklampside serum Troponin I düzeyinin değerlendirilmesi
}

\author{
Evaluation of serum Troponin I Levels in preeclampsia
}

\author{
Sibel Sak ${ }^{1}$, Mahmut Erdemoğlu², Elif Ağaçayak ${ }^{3}$, Ahmet Yalınkaya $^{3}$, Talip Gül ${ }^{3}$
}

\section{ÖZET}

Amaç: Preeklamptik gebelerde troponin I (cTnl) düzeylerini araştırmak, sağlıklı gebelerin değerleri ile karşılaştırmak ve ayrıca preeklampsinin şiddeti ile troponin I düzeyleri arasında ilişki olup olmadığını değerlendirmek amaçlanmıştır.

Yöntemler: Bu çalışmada, Şubat 2009 ile Temmuz 2009 tarihleri arasında Dicle Üniversitesi Tıp Fakültesi Kadın Hastalıkları ve Doğum Anabilim Dalı'na başvuran, ardışık 83 preeklamptik gebe ile medikal problemi olmayan kontrol grubu olarak alınan 40 gebede serum troponin I düzeyleri ölçülmüş ve karşılaştırılmıştır.

Bulgular: Serum cTnl seviyesi ile yaş, VKI, trombosit sayısı, sistolik kan basıncı, diastolik kan basıncı ALT, AST, $\mathrm{LDH}$, üre, kreatinin, hematokrit hemoglobin değerleri arasında ilişki saptanmamıştır. Preeklampsi ve sağlıklı gebelerdeki Troponin I düzeyleri karşılaştırıldığında gruplar arasında anlamlı farklılık saptanmamıştır $(p=0,501)$

Sonuç: Preeklampsi ile troponin I seviyeleri arasında ilişki bulunamadı. Yüksek troponin I düzeyi saptanan preeklamptik gebelerde ileri kardiyolojik tetkik yapılmasının gerekli olduğu değerlendirildi.

Anahtar kelimeler: Troponin I, preeklampsi, gebelik

\section{GíRiş}

Obstetrik tanı ve tedavideki büyük gelişmelere rağmen, preeklampsi gelişmekte olan ülkelerle birlikte gelişmiş ülkelerde de maternal ve fetal morbidite ve mortalitenin önde gelen nedenlerindendir. Fark11 oranlar bildirilmekle beraber, tüm gebeliklerin \%7-10’unda görülür [1]. Preeklampsi; proteinüri, ödem ve sıklıkla diğer organlara ait bozuklukların

\begin{abstract}
Objective: To investigate the troponin I (cTnl) levels in preeclamptic women, compare with the values of healthy pregnant women and also to evaluate whether the association between troponin I levels with severity of preeclampsia.
\end{abstract}

Methods: This study was performed with 83 preeclamptic pregnant women and 40 pregnant women control group having no medical problems who has admitted to the Obstetrics and Gynecology Clinics of Dicle University Medical Faculty between February 2009 and July 2009. Serum troponin I levels were measured and compared between two groups.

Results: There was no correlation between serum cTnl levels with hemoglobin, hematocrit age, BMI, platelet count, systolic blood pressure, diastolic blood pressure, ALT, AST, LDH, urea and creatinine. There was no significant differences between the groups in preeclampsia and healthy pregnant women when compared in terms of Troponin I levels $(p=0.501)$

Conclusion: Preeclampsia was not associated with troponin I levels in our study. So patients with preeclampsia and elevated troponin levels should have further cardiac investigations and close cardiovascular follow-up.

Key words: Troponin I, preeclampsia, pregnancy

eşlik ettiği gebelikle oluşan bir hipertansiyon sendromudur. Bu durum gebe insana özgüdür ve en çok primigravidalarda görülür [2]. Progresif niteliktedir ve ancak doğumda plasenta ve eklerinin vücuttan ayrılması ile son bulur. Tanım olarak; gebeliğin 20 . haftasından sonra, trofoblastik hastalık ve çoğul gebelik varlığında 20. haftadan önce, ortaya çıkan hipertansiyona ödem ve proteinürinin eklenmesine preeklampsi denir [3]. Erken tanı ile tedavisi veya

${ }^{l}$ Siverek Sedef Tıp Merkezi, Diyarbakır, Türkiye

${ }^{2}$ Diyarbakır Özel Genesis Hastanesi Diyarbakır, Türkiye

${ }^{3}$ Dicle Üniversitesi Tıp Fakültesi Kadın Hastalıkları ve Doğum Anabilim Dalı, Diyarbakır, Türkiye

Yazışma Adresi /Correspondence: Sibel Sak, Siverek Sedef Tıp Merkezi, Diyarbakır, Türkiye Email:drsibelsak@gmail.com

Geliş Tarihi / Received: 29.03.2015, Kabul Tarihi / Accepted: 24.04.2015

Copyright @ Dicle Tıp Dergisi 2015, Her hakkı saklıdır / All rights reserved 
buna bağlı komplikasyonların önlenmesi mümkün olabildiğinden fizyopatolojik mekanizması çözümlendiğinde tedavi alanında önemli bir gelişme kaydedilecektir.

Etyopatogenezinde uterin kan damarlarının anormal trofoblast invazyonu, vasküler endotelyal disfonksiyon, anormal nitrik oksit ve lipid metabolizmas1, fetoplasental doku ile maternal doku arasında immünolojik intolerans, gebeliğin inflamatuvar ve kardiyovasküler değişimlerine uyumsuzluk, genetik anomaliler, metabolik ve nutrisyonel faktörler bildirilmektedir [4].

Preeklampsinin fizyopatolojisinde vazospazm esas faktördür. Vazospazm muhtemelen vasküler hasarın da ortaya çıkışına öncülük etmektedir. Preeklampsi fizyopatolojisinin temelinde rol oynayan endotel hasarı ve yaygın vazospazm, azalmış organ perfüzyonuna neden olur. Vazospazm ve bozulmuş organ perfüzyonu, tüm anne organlarını etkilemektedir.

Troponin I, periferik kanda myokardial iskemi sonucu artan myosit hasarının en spesifik ve sensitif yeni nesil biokimyasal belirteçlerinden olup aktin ve miyozinin kalsiyumla etkileşimini düzenleyerek, miyokard kontraksiyonunda görev alan düzenleyici bir proteindir. Troponin I düzeyi, normal gebeliklerden etkilenmediğinden gebelerde myokardial infarkt şüphesinde en yaygın kullanılan kardiak markırdır.

Preeklampsinin, klinik tablo oluşmadan önce tanınması, hekime önemli bir avantaj sağlar. $\mathrm{Bu}$ durumda hastalıktan korunma ve klinik tablonun başlamasını geciktirme mümkün olabilir. Böylece maternal ve neonatal olumsuzluklar önlenebilir. $\mathrm{Bu}$ çalışmadaki amaç, preeklampsinin erken tanısı ve şiddetinin önceden belirlenebilmesi ve prenatal erken dönemde önlem alınabilmesi için serum troponin I seviyesinin risk faktörü olarak kullanılıp kullanılamayacağının ve subklinik (minör) kardiyak hasarın saptanmasıdır.

\section{YÖNTEMLER}

Çalışmaya Dicle Üniversitesi Tıp Fakültesi Kadın Hastalıkları ve Doğum Bölümü'ne Şubat 2009 ile Temmuz 2009 tarihleri arasında başvuran, 24-40 hafta aras 183 preeklamptik gebe ile herhangi bir medikal problemi olmayan 40 normal gebe dahil edildi. Preeklamptik hasta seçimi ve sinıflandırılması Amerikan Obstetrik ve Jinekoloji Derneği kriterlerine göre yapıldı. Buna göre preeklampsi tanıs1; gebelikten önce normotansif olan 20. gestasyonel haftadan büyük olan gebelerde en az 6 saat ara ile yapılan 2 ölçümde, kan basıncının 140/90 mmHg ve idrarda $300 \mathrm{mg} / \mathrm{L}$ protein (en az +1 , dipstik ile) olması ile konuldu. Şiddetli preeklampsi kriterleri kan basıncının 160/110, görme bozukluğu, serebral bozukluk, konvülziyon, baş ağrısı, epigastrik ağrı, sağ omuz ağrısı, bulantı, kusma, serum kreatininde yükselme, trombositopeni $\left(<100.000 / \mathrm{mm}^{3}\right)$, karaciğer fonksiyonlarında veya periferik yaymada bozulma, pulmoner ödem ve siyanoz, anormal umblikal arter doppler bulgularıyla beraber intrauterin gelişme geriliği veya oligohidramnioz olarak alındı. Preeklampsi tanısına uyan ancak ağır preeklampsi kriterlerini taşımayan hastalar hafif preeklampsi olarak sınıflandırıldı. Çoğul gebelik, diabetus mellitus, kronik hipertansiyon, infektif hastalıklar, erken memran rüptürü, polihidramnios ve renal hastalık gibi gebelik öncesi herhangi medikal problemi olanlar çalışmaya dâhil edilmedi.

Kontrol grubuna gebelik öncesi herhangi bir medikal ve obstetrik problemi olmayan böbrek ve karaciğer fonksiyon testleri ve kan basinci normal değerlerde olan gebeler dahil edildi. Her iki grubun sosyodemografik, reproduktif, medikal ve laboratuvar bilgileri, fetüsün ultrasonografik bilgileri hasta takip formlarına kaydedildi. Proteinüri, preeklamptik ve kontrol grubundaki gebelerden alınan spot idrar örneklerinde Combur 10 Test S stripleri kullanılarak Roche Urisys 1800 cihazında ölçüldü. Preeklamptik ve kontrol grubundaki gebelerden, 2 adet antikogulanlı bir adet antikoagulansız vakumlu tüpe 5'er ml kan alındı. Hemogram Cell -dyn 3700 cihazında çalışıldı. Biyokimya tetkikleri ARCHITECT C 800 cihazında çalışıldı. 3000 ppm'de 10 dakika santrifüj edilerek ayrıştırılan Troponin I serumları, $\left(-80^{\circ} \mathrm{C}\right)^{\circ}$ de analiz edilecek tarihe kadar saklandi. Troponin I, Immulate 2500 cihazında STAT Troponın I (Siemens Medical Solution Diagnostics) kiti kullanılarak analitiksel sensivitesi $0.1 \mathrm{ng} / \mathrm{ml}$ olan chemiluminescent immunometrik assay yöntemi ile çalışıldı.

Sürekli değişkenlerin tanımlayıcı istatistikleri için ortalama ve standart sapma değerleri kullanıldı. 
Kesikli değișkenlerin tanımlayıcı istatistikleri için median değerleri kullanıldı. Sürekli değişkenlerin iki grup ortalamasını karşılaştırmak için Student's t testi kullanıldı. Kesikli değişkenlerin iki grup medianlarını karşılaştırmak için Mann-Whitney U testi kullanıldı. Üç ayrı gurubun ortalamasını karşılaştırmak için ANOVA testi kullanıldı. Çapraz tabloların değerlendirilmesinde yates düzeltmeli Ki-kare testi kullanıldı. Korelasyon katsayıları ve analizi için Pearson korelasyon analizi kullanıldı. İstatistik değerlendirmelerde SPSS 15.0 for Windows(SPSS inc. Chicago, IL, USA) paket programı kullanıld1. Değerlendirmelerde, $\mathrm{p}<0.05$ anlamlı farklılık olarak kabul edildi.

\section{BULGULAR}

Preeklampsi grubunda 83 hasta (25 hafif preeklampsi, 58 şiddetli preeklampsi), kontrol grubunda 40 hasta mevcuttu. Hastaların tanımlayıcı özelliklerinin karşılaştırılması tablo 1 'de verilmiştir.

Kontrol grubunda yaş ortalaması $29.76 \pm 7.46$ y11, PE grubunda 29.24 \pm 7.17 y1l bulundu. Gebelik haftas1 ortalamas1 ise, kontrol grubunda $32.79 \pm 4.81$ iken PE grubunda $32.84 \pm 4.11$ hafta idi. Vücut kitle indeksi (VKİ) kontrol grubunda 27.34 $\pm 2.76, \mathrm{PE}$ grubunda $30.23 \pm 3.46$ idi. Kontrol grubu ile preeklampsi arasında yaş ve gebelik haftası açısından istatistiksel farklilık saptanmazken, vücut kitle indeksi PE hastalarında kontrol grubuna göre anlamlı olarak yüksek bulundu (Tablo 1).

Preeklamptik hastaların 61'i(\%73.5) 17-33yaş araliğında,17'si(\%20,5) 34-41 yaş aralığında, 5'i $(\% 6)$ ise 42 ve üzeri yaşta saptandı (Tablo 2). Kontrol grubunun median gravida 3 , parite 2 , preeklamptik grubun median gravida 3, parite 1 bulundu. Kontrol grubu ve preeklamptik grupta gravida ve parite açısından anlamlı fark bulunmadı.
Tablo 1. Hastaların tanımlayıcı özellikleri ve ilk geliş kan basıncı (KB) ve laboratuvar parametrelerinin karşılaştırılması

\begin{tabular}{lccc}
\hline & $\begin{array}{c}\text { Kontrol } \\
(\mathrm{n}=40)\end{array}$ & $\begin{array}{c}\text { Preeklampsi } \\
(\mathrm{n}=83)\end{array}$ & $\mathrm{p}$ \\
\hline Yaş $(\mathrm{yll})$ & $29.76 \pm 7.46$ & $29.24 \pm 7.17$ & 0.741 \\
Gebelik haftası & $32.79 \pm 4.81$ & $32.84 \pm 4.11$ & 0.957 \\
VKi $\left(\mathrm{kg} / \mathrm{m}^{2}\right)$ & $27.34 \pm 2.76$ & $30.23 \pm 3.46$ & $<0.001$ \\
Gravide & 3 & 3 & 0.456 \\
Parite & 2 & 1 & 0.303 \\
Sistolik KB $(\mathrm{mmHg})$ & $113.10 \pm 13.12$ & $146.75 \pm 20.3$ & $<0.000$ \\
Diastolik KB $(\mathrm{mmHg})$ & $68.97 \pm 9.390$ & $93.17 \pm 15.38$ & $<0.000$ \\
Trombosit $\left(\mathrm{mm}{ }^{3}\right)$ & $286.55 \pm 113.77$ & $242.27 \pm 99.31$ & 0.049 \\
Hemoglobin(gr/dl) & $11.79 \pm 1.37$ & $12.95 \pm 1.93$ & 0.004 \\
Hematokrit $(\%)$ & $34.55 \pm 4.47$ & $39.19 \pm 5.81$ & $<0.000$ \\
ALT $(\mathrm{U} / \mathrm{L})$ & $16.10 \pm 4.39$ & $57.02 \pm 143.93$ & 0.011 \\
AST $(\mathrm{U} / \mathrm{L})$ & $18.48 \pm 3.89$ & $85.11 \pm 209.04$ & 0.090 \\
LDH $(\mathrm{U} / \mathrm{L})$ & $153.86 \pm 41.91$ & $496.19 \pm 468.26$ & $<0.000$ \\
Üre (mg/dl) & $15.86 \pm 3.36$ & $25.81 \pm 10.41$ & $<0.000$ \\
Kreatinin(mg/dl) & $0.71 \pm 0.15$ & $0.82 \pm 0.27$ & 0.053 \\
\hline
\end{tabular}

VKI: Vücut kitle indeksi
Çalışmaya dahil edilen 47 nulliparın 36's1 $(\% 76,6)$ preeklamptik idi. Çalışmaya dahil edilen 76 multiparın 47'si $(\% 61,8)$ preeklamptik idi. Kontrol grubu ve preeklamptik grupta nulliparite ve multiparite arasında anlamlı fark bulunmadi. Hastaların laboratuvar ve kan basıncı değerleri karşılaştırıldığında, sistolik ve diastolik kan basınçları, ALT,
$\mathrm{LDH}$, üre, hemoglobin, hematokrit değerleri preeklamptik grupta kontrol grubuna göre istatistiksel olarak anlamlı yüksek bulundu. Trombosit sayıs1, preeklamptik grupta kontrol grubuna göre anlamlı düşük bulundu. AST ve kreatinin değerleri açısından her iki grup arasında anlamlı fark bulunmadı (Tablo 1). 
Üç grubun Troponin I düzeyleri karşılaștırıldığında gruplar arasında anlamlı farklılık saptanmadı $(\mathrm{p}=0.501)$ (Tablo 3). Serum cTnI seviyesi ile yaş, VKİ, trombosit sayıs1, sistolik kan basınc1, diastolik kan basinc1 ALT, AST, LDH, üre, kreatinin, hematokrit hemoglobin değerleri arasında ilişki saptanmadi.

Sistolik ve diastolik kan basıncı değerleri ile troponin değerleri arasında korelasyon olmadığ 1 izlendi. Diastolik kan basıncı ve troponin arasında korelasyon katsayısı $r=-0.102$ ve önem düzeyi $\mathrm{p}=0.295$ bulundu. Sistolik kan basinc1 ve troponin arasinda korelasyon katsayısı $r=-0.089$ ve önem düzeyi $\mathrm{p}=0.359$ bulundu $(\mathrm{r}>0.50, \mathrm{p}<0.05)$.

Tablo 2. Preeklamptik hastaların yaşlara göre dağılımı

\begin{tabular}{ccc}
\hline Yaş aralığı (Yı) & Hasta sayısı $(\mathrm{n}=83)$ & Oran $(\%)$ \\
\hline $17-33$ & 61 & 73.5 \\
$34-41$ & 17 & 20.5 \\
$>42$ & 5 & 6 \\
\hline
\end{tabular}

Tablo 3. Hafif preeklampsi, şiddetli preeklampsi ve kontrol grubunun troponin I seviyelerinin karşılaştırılması (Ortalama \pm Standart deviasyon)

\begin{tabular}{lcccc}
\hline & $\begin{array}{c}\text { Kontrol } \\
(\mathrm{n}=40)\end{array}$ & $\begin{array}{c}\text { Hafif preeklampsi } \\
(\mathrm{n}=25)\end{array}$ & $\begin{array}{c}\text { Ağır Preeklampsi } \\
(\mathrm{n}=58)\end{array}$ & $\mathrm{p}$ \\
\hline Troponin I & $0.325+0.55$ & $0.196+0.17$ & $0.504+0.703$ & 0.501 \\
\hline
\end{tabular}

ANOVA testi kullanılmıştır.
Tablo 4. Serum troponin I (cTnl) seviyesi ile VKI yaş, kan basıncı ve laboratuvar parametreleri arasındaki korelasyon

\begin{tabular}{lcc}
\hline & $r$ & $p$ \\
\hline cTnl-VKi & 0.075 & 0.359 \\
cTnl-Yaş & -0.13 & 0.17 \\
cTnl-Sistolik KB & -0.089 & 0.436 \\
cTnl-Diyastolik KB & -0.102 & 0.295 \\
cTnl-ALT & -0.048 & 0.619 \\
cTnl-AST & -0.047 & 0.031 \\
CTnl-LDH & -0.037 & 0.701 \\
cTnl-Kreatinin & 0.152 & 0.114 \\
CTnl-Üre & 0.160 & 0.096 \\
cTnl-Trombosit & -0.012 & 0.900 \\
cTnl-Hemoglobin & 0.130 & 0.047 \\
cTnl-Hematokrit & 0.191 & 0.001 \\
\hline
\end{tabular}

r: Korelasyon katsayısı, VKI: Vücut kitle indeksi, KB: Kan basıncı

\section{TARTIŞMA}

Preeklampsi, genellikle primigravidalarda, molar gebelik, hidrops fetalis ve çoğul gebelikler dişında 20. gebelik haftasından sonra ortaya çıkan ve sadece plasental doku mevcudiyetinde gelişen hipertansiyon $(140 / 90)$ ve proteinüri $(300 \mathrm{mg} \backslash 24$ saat veya en az 1+ dipstick ile) ile seyreden hastalık olarak tarif edilir. Gebe popülasyonda ortalama insidans $\% 6-7$ olarak kabul edilir.
Etyopatogenezinde uterin kan damarlarının anormal trofoblast invazyonu, vasküler endotelyal disfonksiyon, anormal nitrik oksit ve lipid metabolizmas1, fetoplasental doku ile maternal doku arasinda immünolojik intolerans, gebeliğin inflamatuvar ve kardiyovasküler değişimlerine uyumsuzluk, genetik anomaliler ve metabolik ve nutrisyonel faktörler bildirilmektedir [4].

Maternal mortalite ve morbidite nedeni olan preeeklampsi ve eklampsi aynı zamanda perinatal mortalite, gelişme geriliği, erken doğum eylemi sonucu prematürite gibi önemli fetal komplikasyonlara da neden olmaktadır [5].

Akut miyokardial infarkt gebelikte nadir$\operatorname{dir}(1 / 10000-1 / 30.000)$. Ancak çocuk doğurma yaşının artması ve reprodüktif teknolojinin ilerlemesi daha ileri yaştaki kadınların gebe kalmasına neden olmakta ve sonuç olarak myokardial infarktın gebelikte oluşma sıklığını artırmaktadır [6]. Gebelik AMI riskini 3-4 kat artırmaktadır [7].

Son y1llarda miyokardial hasar göstergesi olan kardiyak troponin I ve kardiyak troponin $\mathrm{T}(\mathrm{CTn})$ kullanıma girmiştir [8]. CTn'lerin kardiyak spesifitesi CK-MB'den daha yüksektir. Ebell ve ark. [9]. troponin testlerinin, miyokard enfarktüsü için eşit duyarlı1ık (\%63) ve özgüllükde (TnT: \%91, TnI: \%92) olduğunu göstermiştir. Lestin ve ark. [10]. MI şüphesi ile hastaneye yatırılan hastalarda TnI ve TnT karşılaştırması yapmış ve benzer tanısal duyar- 
l1lık (\%100'e yakın) gözlemişlerdir. Pagani ve ark. [11] her iki troponinin de akut MI için neredeyse tamamen duyarlı olduğunu (\%100 cTnI, \%98 cTnT) ve özgüllüğün cTnI için oldukça yüksek olduğunu (\%68.1'e karşılık \%78,7) saptamışlardır.

Shiver ve ark. [12] yaptıkları bir çalışmada 51 gebede doğum öncesi, doğumun 2.evresinde ve doğumdan 30 dakika, 12saat ve 24 saat sonrasında hastalarda CK, CK-MB, miyoglobin ve troponin I çalışmışlar. Doğum öncesi tüm belirteçleri, normal üst limitin altında bulmuşlardır. CK, CK-MB, miyoglobin değerleri doğumdan sonraki 30.dakikada yaklaşık 2 kat yüksekliğe ulaşırken, troponın I düzeyi tüm dönemlerde cut off değerin altında kalmıştir.

Çalışmamızda, preeklamptik hastalarda minör kardiyak hasarı tespit etmek ve bu kardiyak hasarın preeklampsinin ciddiyeti ile ilişkisini saptamak için en sensitif ve spesifik kardiyak belirteç olan troponin I düzeyinin değerlendirilmesini amaçladık.

Yang ve ark. [13], sağlıklı gebelerde, hafif ve ağır preeklamptik gebelerde troponin I düzeyini araştırmışlardır. Preeklamptik gebelerde, sağlıklı gebelere göre troponin I düzeyini anlamlı yüksek bulmuşlar ancak hafif ve ağır preeklampsi arasında anlamlı bir fark bulamamışlardır. Bizim çalışmamızda, üç grup arasında troponin I düzeyleri arasında anlamlı fark bulunamadi.

Kale ve ark. [14], preeklampside kardiyak troponin I, CK-MB ve miyoglobin değerlerini araştırmışlar ve miyoglobin ve CK-MB değerleri anlamlı bulunmazken troponin I düzeyini anlamlı yüksek bulmuşlardır.

Atalay ve ark[15], preeklamptik hastalarda troponin I düzeyinin anlamlı oranda arttığını, magnezyum sülfat tedavisinin troponin I düzeylerini düşürdüğünü bildirmişlerdir. Biz çalışmamızda, troponin I düzeyi için serum örneklerini hasta kliniğe ilk başvurduğunda, herhangi bir antihipertansif veya antikonvulsif $\left(\mathrm{MgSO}_{4}\right)$ ajan başlanmadan aldığımızdan $\mathrm{MgSO}_{4}$ başladığımız ağır preeklamptik hastalarımızda $\mathrm{MgSO}_{4}$ 'ün olası troponin I düzeylerini düşürücü etkisi çalışmamızı etkilememiştir.

Engin ve ark. [16] hipertansif gebe kadınlarda ve preterm eylem tanısı alıp doğum yapmış kadınlarda göbek kordon kanında troponin I düzeyini ölçmüşler ve her iki grupta da troponin I'yı anlamlı yüksek bulmuşlardır.

Becerikli ve ark. [17], yaptıkları bir çalışmada antihipertansif(metil-dopa) tedavi alan preeklamptik ve gestasyonel hipertansif hastalarla, antihipertansif(metil-dopa) ve antikonvülzyon (magnezyumsülfat) alan hastaları (Ağır preeklampsi), kontrol grubu ile troponin $\mathrm{T}$ açısından karşılaştırmışlardır. Troponin T'yi her iki grupta kontrol grubuna göre yüksek bulmuşladır. Antikonvülzyon tedavi alan grupta sadece antihipertansif tedavi alan gruba göre troponin T seviyeleri daha yüksek bulunmuştur. $\mathrm{Bu}$ yüksekliğin hastalığın şiddetinden mi veya magnezyum sülfat kullanımından mı kaynaklandığını açıklayamamışlardır. (magnezyum sülfatın kardiyotoksik etkisi).

Shelton ve ark. [18], magnezyum sülfatın kardiyak etkilerini araştırmak üzere preeklamptik hastalarda yaptıkları çalışmada intrauterin magnezyum sülfata maruz kalmış yenidoğanlarda kardiyak troponin-T seviyesinin daha yüksek olduğunu göstermişlerdir.

Yaptığımız çalışmada PE ile kontrol grubu arasında yaş, gestasyonel hafta, gravide, parite, arasında fark saptanmamıştır. Vücut kitle indeksi, PE'de kontrole göre anlamlı yüksek bulunmuştur. $\mathrm{Bu}$ bulgu obesitenin PE gelişme riskini arttırdığ 1 tezini desteklemektedir. Hipertansiyon varlığı ve preeklamptik gebelerdeki esas fizyopatolojinin vazospazm ve buna bağlı azalmış organ perfüzyonu olduğu bilinmesine rağmen preeklamptik gebelerde troponin I yüksekliği saptanmadi. Preeklamptik preterm doğum yapan annelerin gelecekte geç kardiyovasküler nedenli ölümler için aday olduğunu [19] bilmemize rağmen ve popülasyon bazlı bir çok çalışmanın geç dönem maternal kardiyovasküler riskleri bildirmesine rağmen [20] hasta serimizdeki troponin I düzeyleri kardiyak hasarı desteklememektedir. Oysaki; pozitif troponın I düzeyleri uzun dönem kardiyovasküler hastalıklar için uyarıcı olabilirdi. Çünki bilindiği gibi endotel disfonksiyonu sonucu oluşan süreç, gebeliğin terminasyonu ile sonlanmamakta ve uzun yillar persiste etmektedir.

Preeklampside aminotransferazların yükselmesi, üre, kreatinin yükselmesi, vizual bozukluklar, karın ağrısı, baş ağrısı hedef organ perfüzyonunun bozulmasına bağlanırken bizim çalışmamızda mi- 
yokard perfüzyon bozukluğunu gösteren troponin I'nın artmaması preeklampsideki farklı end organ etkilenimlerinin paralel olmadığını göstermektedir. $\mathrm{Bu}$ nedenle preeklampsideki organ disfonksyonunu tüm spektrumuyla anlamak için, çoklu organ fonksyon değerlendirmesi yapmak gerekir.

Çalışmamızda, serum cTnI seviyesi ile yaş, VKİ, trombosit sayısı, sistolik kan basınc1, diastolik kan basincı ALT, AST, LDH, üre, kreatinin, hematokrit hemoglobin değerleri arasında da ilişki saptanmamıştır.

Konu ile ilgili literatür araştırıldığında çalışmamızı destekleyen iki yayına ulaşılabildi. Joyal ve ark.([21], 20 preeklamptik ve 19 sağlıklı gebede troponin I düzeyini araştırmışlar ve preeklamptik gebelerde troponin I düzeyini anlamlı yüksek bulmamışlardır. Bu nedenle preeklampsi olup ta yüksek troponin I seviyesi olan hastalarda ileri kardiyak araştırma önermişlerdir.

Sprawka ve ark. [22], 17 hafif ve 17 ağır preeklamptik hastada troponin I düzeyini ölçmüşler, preeklampsi ile troponiın I düzeyi arasında anlamlı bir ilişki saptamamışlardır. Preeklamptik gebelerdeki troponin I yüksekliğinin, bu hastalığın genel bir özelliği olmayıp miyokard infarktını düşündürmesi gerektiğini bildirmişlerdir.

Sonuç olarak, preeklampsi ile troponin I düzeyi arasında istatistiksel olarak anlamlı bir ilişki saptanmadi. Ancak literatürde preeklampsi ile troponin I arasındaki pozitif ilişkiyi belirten yayınlar da olduğundan preeklamptik hastalardaki troponin I yüksekliği dikkatle değerlendirilmeli ileri kardiyak araştırma ve yakın kardiyak takip yapılmalıdır.

\section{KAYNAKLAR}

1. Hallak M. James DK, Steer PJ, Weiner CP, et al. High Risk Pregnancy Management Options Hypertension in pregnancy .W.B.Saunders, second edition. Philadelphia 2006:772797.

2. Scott R: Danforth Obstetrics and Gynecology, 9th edition. Hypertensive Disorders of Pregnancy J.B. Lippincott company. Philadelphia 2003:257-271.

3. Durukan T. Kişnişçi HA, Göksin E,et al. Temel Kadın Hastalıkları ve Doğum Bilgisi. Gebelikte hipertansiyon, preeklampsi-eklampsi. Güneş Kitabevi, Ankara 1996:1647-1651.

4. Dekker GA, Sibai BM. Pathogenesis and etiology of preeclampsia. Am J Obstet Gynecol 1998;179:1359.

5. Jonel S, Lockwood CJ, Berkowitz SG, et al. Risk factors for severe preeclampsia. Obstet Gynaecol 1994;83:357-361.
6. Paulson RJ, Boostanfar R, Saadat P, et al. Pregnancy in the sixth decade of life: obstetric outcomes in women of advanced reproductive age. JAMA 2002;288:2320-2323.

7. Roth A, Elkayam U. Acute myocardial infarction associated with pregnancy an update. Ann Intern Med 1996;125:751762.

8. Adams JE, Bodor GS, Davilla-Roman VG, et al. Cardiac troponin I. A marker with high specifity for cardiac injury. Circulation 1994;89:1447-1448.

9. Ebell MH, Flewelling D, Flynn CA. A systematic review of Troponin $\mathrm{T}$ and I for diagnosing acute myocardial infarction. J Fam Practice 2000;49:550-556.

10. Lestin M, Hergert M, Lestin HG, ve ark. Evaluation of the chemiluminescence immunoassays for the measurement of troponin I, myoglobin and CK-MB using the IMMULITE system in comparison to other measuring systems. Clin Lab 2000;48:211-221.220.

11. Panteghini M, Pagani F, Kiang-Teck JY, ve ark. Comparative study of cardiac Troponin I and T measurements in a routine extra-cardiological clinical setting. J Clin Lab Analy Evaluation 2004;15:210-214.

12. Shivvers SA, Wians FH, Keffer JH, et al. Maternal cardiac troponin I levels during normal labor and delivery. Am J Obstet Gynecol 1999;180:122-127.

13. Yang X, Wang H, Wang Z, et al. Alteration and significance of serum cardiac troponin I and cystatin $\mathrm{C}$ in preeclampsia Clin Chim Acta 2006;374:168-169.

14. Kale A, Ecer S,Kale E. Preeklampside Kardiyak Troponin I, CK-MB ve Myoglobin Değerleri Dicle Tıp Dergisi 2005;32:109-112.

15. Atalay C, Erden G, Turhan T,et al. The effect of magnesium sulfate treatment on serum cardiac troponin I levels in preeclamptic women. Acta Obstet Gynecol Scand 2005;84:617-621.

16. Engin Y, Ustun Y, Kurtay G. Cardiac troponin I levels in umbilical cord blood. Int J Gynaecol Obstet 2002;77:239241.

17. Becerikli F,Çağlar G, GüngörT, et al. Preeklampsi ve gestasyonel hipertansiyonda kardiyak troponin T ,CK-MB ve myoglobulin değerleri, T Klin Jinekol Obst 2004, 14.

18. Shelton SD, Fouse BL, Holleman CM, et al. Cardiac troponin T levels in umbilical cord blood. Am J Obstet Gynecol 1999;181:1259-1262.

19. Massey D. Commentary: Clinical diagnostic use of cystatin C. J Clin Lab Anal 2004; 18:55-60.

20. Babay Z, Al-Wakeel J, Addar M, et al. Serum cystatin C in pregnant values, reliable and superior diagnostic accuracy. Clin Exp Obstet Gynecol 2005;32:175-179.

21. Joyal D, Leya F, Koh M, et al. Troponin I Levels in Patients with Preeclampsia, Am J Med 2007;120:13-14.

22. Sprawka N, Timmins A, Sangi-Haghpeykar H, et al. Coonrod Troponin I levels in severe and mild preeclampsia Am J Obstet Gynecol 2008;199:6,174. 